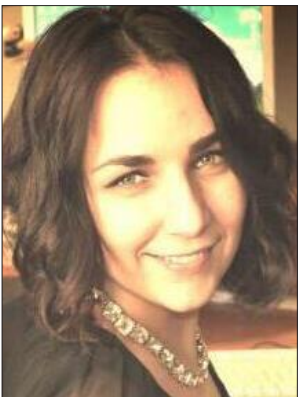

Inna Yu.

Denysenko,

Денисенко Інна Юріївна

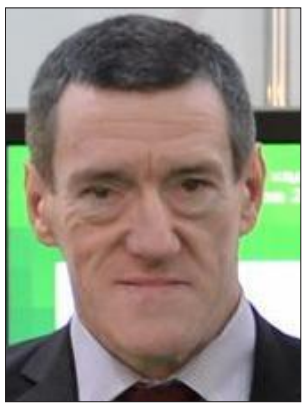

Taras H. Ivashchenko,

Іващенко Тарас Григорович

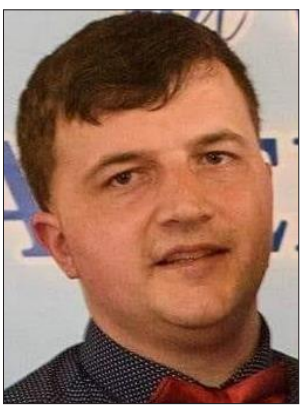

Volodymyr L. Pechenyi,

Печений Володимир Леонідович
УДК 504.75.05

\section{ENVIRONMENTAL MONITORING SYSTEM} IN UKRAINE: PROBLEMS AND WAYS TO SOLVE THEM

\section{СИСТЕМА МОНІТОРИНГУ ДОВКІЛЛЯ В УКРАЇНІ: ПРОБЛЕМИ ТА ШЛЯХИ ЇХ ВИРІШЕННЯ}

\author{
Dol https:// doi.org/10.15589/smi2020.1(13).7
}

Inna Yu. Denysenko

Денисенко Інна Юріївна, канд. тех. наук, доц. Denisenko15@ukr.net

Taras H. Ivashchenko

Іващенко Тарас Григорович, канд. тех. наук, проф. t1313@ukr.net

Volodymyr L. Pechenyi Печений Володимир Леонідович, асистент

State Ecological of Post-Graduate Education and Management, Kyiv

Державна екологічна академія післядипломної освіти та управління, м. Київ

Abstract. Due to the neglect of objective laws of development and reproduction of the natural resource complex of Ukraine, currently, the ecological situation of our country is in crisis. The reason for this is, to a greater extent, environmental factors, namely: structural deformation of the economy due to the dominance of raw materials and resource-intensive production; lack of environmental justification of economic development plans and projects developed by the relevant departments of the ministries on the basis of relevant regulations; there are almost no effective legal, administrative and economic mechanisms for environmental protection; low moral level of society and lack of environmental thinking of the management. As a result, this has led to a rapid regression of Ukraine's environment, excessive pollution of the hydrosphere, atmosphere and lithosphere, the accumulation of large amounts of harmful, including highly toxic, industrial waste.

That is why the priority areas of the existing environmental monitoring system are the control of pollution levels in the components of the environment.

Monitoring on an ongoing basis will provide information on the state of the environment in "real time", which will allow to respond in a timely manner and make the necessary decisions to improve the situation.

The results of this work are: analysis of the functioning of the environmental monitoring system in Ukraine; indication of criteria and requirements for effective functioning of the environmental monitoring system; providing ways to improve the system of monitoring the state of the environment in order to improve the environmental safety of the individual region and the state as a whole.

In the current system of monitoring the state of the atmosphere of Ukraine, the collection and processing of information is almost not automated, based on laboratory-chemical methods of sample analysis and used more for statistical analysis. This functioning of the monitoring system is due to the low level of unification of the regulatory framework, technical support and interaction of its subjects, as well as insufficient funding for the work, which in turn does not allow the relevant authorities to effectively manage air quality at different levels. to prevent negative changes in the state of the environment and compliance with environmental safety requirements.

Key words: ecological safety, technogenic safety, monitoring of the state of the environment, control of the state of the environment, pollution.

Анотація. Через нехтування об’єктивними законами розвитку і відтворення природноресурсного комплексу України екологічну ситуацію в нашій державі можна охарактеризувати як кризову.

Причиною цього більшою мірою виступають екологічні чинники, а саме структурна деформація господарства 3 домінуванням сировинно-видобувного та ресурсоємного виробництва; відсутність екологічного обгрунтування планів і проєктів економічного розвитку, що розробляються відповідними підрозділами міністерств на підставі відповідних нормативних документів; майже відсутні ефективно діючі правові, адміністра- 
тивні й економічні механізми захисту навколишнього середовища; низький моральний рівень суспільства та відсутність екологічного мислення керівної ланки.

Як наслідок, це призвело до стрімкої регресії довкілля України, надмірного забруднення гідросфери, атмосфери та літосфери, накопичення у великих кількостях шкідливих, у т. ч. високотоксичних, відходів виробництва. Саме тому пріоритетними напрямами чинної системи екологічного моніторингу довкілля є контроль за рівнями забруднення в компонентах навколишнього середовища.

Ведення моніторингу на постійній основі забезпечить отримання інформації про стан довкілля у «реальному часі», що дасть можливість вчасно відреагувати та приймати необхідні рішення для поліпшення ситуації.

Результатами проведеної роботи є: аналіз функціонування системи екологічного моніторингу в Україні; зазначення критеріїв і вимог для ефективного функціонування системи моніторингу довкілля; наведення шляхів покращення системи моніторингу стану навколишнього природного середовища 3 метою поліпшення екологічної безпеки окремого регіону і держави загалом.

У чинній системі спостережень за станом атмосфери України збір та обробка інформації майже не автоматизована, побудована на лабораторно-хімічних методах аналізу проб і використовується більше для статистичного аналізу. Таке функціонування системи моніторингу зумовлене низьким рівнем уніфікації нормативно-методичної бази, технічного забезпечення та взаємодії іiі суб'єктів, а також недостатнім об'ємом фінансування робіт, що практично не дає змоги відповідним органам ефективно здійснювати управління якістю повітря на різних рівнях для запобігання негативним змінам стану середовища та дотримання вимог екологічної безпеки.

Ключові слова: екологічна безпека; техногенна безпека; моніторинг стану навколишнього природного середовища; контроль стану навколишнього середовища; забруднення.

\section{References}

[1] Pro okhoronu atmosfernoho povitrya : Zakon Ukrayiny vid 16.10.1992 № 2708-XII. Vidomosti Verkhovnoyi Rady Ukrayiny. 1992. № 50, St. 679.

[2] Pro metrolohiyu ta metrolohichnu diyal'nist' : Zakon Ukrayiny vid 03.07.2019 № 1314-VII. Vidomosti Verkhovnoyi Rady Ukrayiny. 2019. № 28, St. 116.

[3] Pro zatverdzhennya Polozhennya pro derzhavnu systemu monitorynhu dovkillya : Postanova Kabinetu Ministriv Ukrayiny vid 30.03.98 № 391 .

[4] Pro zatverdzhennya Poryadku orhanizatsiyi ta provedennya monitorynhu v haluzi okhorony atmosfernoho povitrya : Postanova Kabinetu Ministriv Ukrayiny vid 09.03.99 № 343.

[5] Pro zatverdzhennya Pravyl stvorennya ta ekspluatatsiyi avtomatyzovanykh system ekolohichnoho kontrolyu i monitorynhu ob’yektiv pidvyshchenoyi ekolohichnoyi nebezpeky ta Rehlamentu stvorennya ta funktsionuvannya avtomatyzovanykh system ekolohichnoho kontrolyu i monitorynhu ob’yektiv pidvyshchenoyi ekolohichnoyi nebezpeky : Nakaz Ministerstva okhorony navkolyshn’oho seredovyshcha Ukrayiny vid 27.03.2009 № 148.

[6] HOST 34.601-89. Ynformatsyonnaya tekhnolohyya. Kompleks standartov na avtomatyzyrovannye systemy. Avtomatyzyrovannye systemy. Stadyy sozdanyya. [Deystvytelen ot 1990.12.29]. Moskva : Standartynfo, 2009 . p. 11.

[7] HOST 34.603-92. Vydy yspytanyy avtomatyzyrovannykh system. [Deystvytelen ot 1992.02.17]. Moskva : Standartynfo, 2009. p. 10.

[8] HOST 34.601-89. Informatsyonnaya tekhnolohyya. Kompleks standartov na avtomatyzyrovannye systemy. Avtomatyzyrovannye systemy. Stadyy sozdanyya. [Deystvytelen ot 1990.12.29]. Moskva : Standartynfo, 2009. p. 11.

[9] DSTU 2156-93. Bezpechnist' promyslovykh pidpryyemstv. Terminy ta vyznachennya. [Chynyy vid 1995.01.01]. Nakaz vid 27.12.1993 № 208.

[10] HOST 34.201-89 “Vydy, komplektnost' y oboznachenyya dokumentov pry sozdanyy avtomatyzyrovannykh system” : Postanovlenye Hosudarstvennoho komyteta SSSR po standartam ot 24.03.89 № 664 .

[11] RD 50-34.698-90 Avtomatyzyrovannye systemy. Trebovanyya k soderzhanyyu dokumentov. Izdatel'stvo standartov, 2002.

[12] RD 211.0.8.107-05. Metodychni rekomendatsiyi z pytan'stvorennya system monitorynhu dovkillya rehional'noho rivnya : Nakaz Ministerstva okhorony navkolyshn’oho pryrodnoho seredovyshcha Ukrayiny vid 16.12.2005 № 467.

[13] Kachyns'kyy A.B. Ekolohichna bezpeka Ukrayiny: systemnyy analiz perspektyv pokrashchennya. Kyiv: NISD, 2001. p. 312.

[14] Kachyns'kyy A.B. Ekolohichna bezpeka Ukrayiny: systemni pryntsypy ta metody yiyi formalizatsiyi. Natsional'na bezpeka: ukrayins 'kyy vymir. 2009. № 4, pp. 71-79. 
Постановка проблеми. Нинішню екологічну ситуацію в Україні можна охарактеризувати як кризову, що формувалася протягом тривалого періоду через нехтування об'єктивними законами розвитку і відтворення природно-ресурсного комплексу України.

Причиною кризового екологічного становища України є переважно економічні чинники, зокрема:

- структурна деформація господарства 3 домінуванням сировинно-видобувного та ресурсоємного виробництва, впровадження та нарощування яких здійснювалося найбільш «дешевим» способом - без будівництва відповідних очисних споруд;

- відсутність екологічного обгрунтування планів і проектів економічного розвитку, що розробляються відповідними підрозділами міністерств на підставі методик та інструкцій, нормативно-технічної документації з розміщення, будівництва й експлуатації господарських об'єктів і комплексів, на створення нової техніки, технологій і матеріалів;

- майже відсутні ефективно діючі правові, адміністративні й економічні механізми захисту навколишнього середовища;

- низький моральний рівень суспільства та відсутність екологічного мислення керівної ланки.

Ці та інші чинники, зокрема низький рівень екологічної свідомості суспільства, призвели до значної деградації довкілля України, надмірного забруднення поверхневих і підземних вод, повітря, земель, нагромадження у дуже великих кількостях шкідливих, У т. ч. високотоксичних, відходів виробництва.

Основний матеріал (результати). Забезпечення екологічної безпеки $є$ основним способом розв'язання екологічних проблем, який гарантує громадянам розвиток і проживання в біосферосумісній формі, відкриває нові можливості для інших форм діяльності у сфері національної безпеки - воєнної, політичної, економічної, соціальної тощо [1-5].

Чітка послідовність дій, спрямованих на врегулювання якості навколишнього середовища як надзвичайно важливої передумови переходу на моделі сталого розвитку економіки, залежить від цілої низки чинників. Серед них першочергового значення на сучасному етапі ринкових трансформацій в Україні набувають:

- організація моніторингу забруднень і джерел забруднення, визначення рівнів забруднення всіх складових елементів і ресурсів природного середовища, виявлення найнебезпечніших для здоров'я людини місць;

- організація системного моніторингу за трансформацією ландшафтів, агроландшафтів, зміною стану наземних і водних екосистем під впливом антропотехногенних навантажень;

- оцінка негативних впливів на людину й екосистеми стосовно гранично допустимих і критичних рівнів забруднень та антропотехногенних навантажень, а також розробка критеріїв допустимості та критичності цих впливів на різні елементи біосфери та людину;
- оцінка екологічної, економічної, соціальної й естетичної шкоди, яка завдається навколишньому середовищу внаслідок його забруднення і деградації;

- прогноз динаміки антропотехногенних впливів i навантажень на біосферу, а також оцінка негативних наслідків, які виникають;

- розробка ефективних та екобезпечних технікотехнологічних рішень, оптимальне, з погляду екологічних критеріїв, розміщення підприємств і виробництв, що дасть можливість істотно зменшити негативні навантаження на природу;

- визначення напрямів, способів і методів реструктуризації та модернізації еконебезпечних виробництв і підприємств [6-8].

Розвиток інформаційних систем екологічного управління $є$ прерогативою держави, корпорацій i одним із основних напрямів національної політики інформатизації. Чітко налагоджена система екологічного моніторингу дає загальне уявлення про особливості сучасного екологічного стану, основні напрями державної політики у галузі охорони довкілля, використання природних ресурсів і забезпечення екологічної безпеки. В Україні існує доволі розгалужена система екологічного моніторингу стану навколишнього середовища. На рівні держави, регіонів і міст інформація про стан довкілля за певний період формується різними державними установами та підпорядкованими їм підприємствами.

На регіональному рівні підхід до моніторингу заснований на тому, що забруднювальні речовини, потрапивши у кругообіг речовин у біосфері, змінюють стан абіотичного складника та, як наслідок, викликають зміни в біоті. Будь-який господарський захід, проведений у масштабі регіону, позначається на регіональному фоні - змінює стан рівноваги абіотичного і біологічного компонентів. Наприклад, стан рослинного покриву, насамперед лісів, істотно впливає на кліматичні умови регіону.

Особливо складні проблеми екологічного моніторингу на глобальному рівні. Донині цілі такого моніторингу недостатньо чітко сформульовано [9]. Крім того, моніторинг на локальному і регіональному рівнях зазвичай $є$ внутрішньодержавною справою, тоді як глобальний моніторинг - завдання світового рівня, тому що він відповідає інтересам усього людства.

В Україні спостереження за станом атмосферного повітря та вмістом забруднювальних речовин, у т. ч. радіонуклідів, здійснюють такі суб'єкти ДСМД: Мінекоенерго, Гідрометком, Міністерство надзвичайних ситуацій (МНС), Міністерство охорони здоров'я (MO3), їхні органи на місцях, підприємства, установи, організації, діяльність яких призводить або може призвести до погіршення стану атмосферного повітря [10-13].

До об’єктів моніторингу атмосферного повітря належать: атмосферне повітря, у т. ч. атмосферні опади, та викиди забруднювальних речовин в атмосферне повітря. 
Правовою основою організації моніторингу атмосферного повітря в Україні є Закон України «Про охорону атмосферного повітря». Діяльність у сфері моніторингу атмосферного повітря регламентовано Порядком організації та проведення моніторингу у сфері охорони атмосферного повітря.

Мережа спостережень має бути побудована так, щоб дані спостережень відображали стан всього регіону і насамперед пріоритетних об'єктів.

Об’єктом автоматизації є процеси вимірювання, обробки, відображення та зберігання інформації про контрольовані параметри в точках контролю атмосферного повітря, а так само передачі цієї інформації зацікавленим респондентам [14].

Експлуатація об'єкта автоматизації проводиться безперервно, за умов навколишнього середовища, яке відповідає макрокліматичному району з помірним кліматом (Київська область), і встановлюються 54 пости контролю.

Автоматизації підлягають процеси вимірювання, обробки, зберігання інформації щодо контрольованих параметрів атмосферного повітря на постах контролю.

Параметри, що контролюються:

a) пил;

б) оксид сірки;

в) окис вуглецю;

г) двоокис;

д) метан;

е) потужність еквівалентної дози гамма-випромінювання.

Додатково на посту контролюються:

а) контрольовані метеопараметри;

б) температура повітря;

в) швидкість вітру;

г) напрямок вітру;

д) вологість атмосферного повітря;

е) тиск атмосферного повітря.

Передача даних із постів контролю на СЗД (станції збору даних) здійснюється за допомогою каналу зв'язку стандарту GSM 3G.

Технічні засоби нижнього рівня повинні включати засоби вимірювання, перетворення і передачі даних і розташовуватися на постах спостереження. На іцьому рівні здійснюється перетворення вимірюваних фізичних параметрів в уніфіковані сигнали для передачі даних вимірювань на середній рівень. Для передачі даних на середній рівень системи використовують апаратну реалізацію інтерфейсу RS-485.

На середньому рівні здійснюються обробка сигналів із нижнього рівня, формування цифрових потоків для передачі інформації на верхній рівень. Для передачі даних на верхній рівень СЗД використовують канал зв'язку GSM стандарту 3G з виділеною статичною IP-адресою.

Для функціонування СЗД необхідно забезпечити доступ до мережі Internet із виділенням статичної IPадреси.
Користувачі системи АСМ (автоматизованої системи моніторингу) повинні бути забезпечені доступом в Internet.

Технічне обслуговування АCM здійснюється навченим персоналом. Кількість робочих місць - 1 (як варіант - санітарна лабораторія).

Вимоги до кваліфікації персоналу встановлюються чинними нормативними документами з урахуванням конкретних особливостей, що використовуються у системі технічних засобів.

Персонал повинен пройти спеціальну підготовку з вивчення системи, інструкцій з експлуатації та технічного обслуговування із залученням розробників до введення системи в дослідну експлуатацію.

Серед користувачів інформаційних ресурсів АСМ визначаються три основні категорії:

- постійні, інформація яким надається згідно 3 узгодженим регламентом, що враховує інформаційні потреби цих користувачів;

- користувачі, котрі звертаються за нерегламентованим запитом;

- засоби масової інформації для інформування громадськості.

До постійних користувачів інформації належать державні та місцеві органи виконавчої влади, органи місцевого самоврядування, суб'єкти АСМ.

Автоматизована система моніторингу (АСM) становить сукупність приладів і елементів, призначених для виконання функцій (контролю за параметрами повітряного середовища, оповіщення персоналу, передачі сигналів на пульт спостереження і т. ін.)

Пункт контролю і моніторингу є комплексом комунікаційних і програмно-технічних засобів, які розміщені в певному місці та призначені для прийому даних, обробки інформації та видачі iï в заданому форматі про стан параметрів, що контролюються, реєстрації цих вимірів і передачі їх на наступний рівень системи.

Реальний масштаб часу - це масштаб часу, в якому ведеться обслуговування процесу управління впливом на об'єкт контролю (моніторингу) з метою фіксації фізичних параметрів вимірюваних величин.

ACM повинна функціонувати безперервно у всіх режимах експлуатації підприємств Київської області.

Пост контролю - всепогодний автономний антивандальний контейнер із розміщеним обладнанням. Устаткування розміщується згідно з вимогами ергономіки та технічних умов на його складові частини.

Система повинна передбачати можливість іï розширення для аналізу викидів в атмосферне повітря.

Кількість робочих місць при експлуатації системи -5 .

Для забезпечення діагностики, реконфігурації системи та метрологічної повірки (калібрування) вимірювальних елементів повинен бути передбачений технологічний режим. У технологічному режимі функціонування повинні проводитися:

а) конфігурація системи;

б) тестові перевірки обладнання АСМ. 
Функціонально АСМ повинна складатися із трьох рівнів: нижнього, середнього та верхнього.

Технічні засоби нижнього рівня повинні включати засоби вимірювання, перетворення і передачі даних і розташовуватися на постах. На цьому рівні здійснюється перетворення вимірюваних фізичних параметрів в уніфіковані сигнали для передачі даних вимірювань на середній рівень.

Технічні засоби нижнього рівня повинні включати засоби для виконання функцій збору і первинної обробки інформації. Вимірювані параметри: пил, оксид сірки, окис вуглецю, двоокис азоту. Метеорологічні параметри атмосферного повітря на постах контролю: температура, вологість, тиск атмосферного повітря, швидкість вітру і напрямок вітру.

На середньому рівні здійснюються збір і обробка даних із нижнього рівня, архівування цих даних, передача їх на верхній рівень системи.

Технічні засоби середнього рівня повинні включати засоби, призначені для виконання таких функцій, як:

- прийом і обробка інформації від технічних засобів нижнього рівня;

- візуалізація інформації про параметри атмосферного повітря і технологічні параметри, отримані від технічних засобів нижнього рівня;

- зберігання інформації про технологічні параметри та події, що сталися в АСМ;

- інформування про перевищення рівнів вимірюваних параметрів;

- передача даних по каналу GSM на верхній рівень системи АСМ, введення змінних параметрів і виконання конфігурації системи;

- тестування технічних засобів АCM.

Система верхнього рівня повинна включати апаратно-програмний комплекс, до якого належать:

а) база даних;

б) система зберігання даних; 1 од.

в) автоматизоване робоче місце (далі - АРМ) -

АРМ є робочим місцем на основі стаціонарного персонального комп'ютера.

Призначення АРМ:

- моніторинг значень параметрів вимірюваного середовища;

- налаштування системи (конфігурація);

- адміністрування користувачів системи;

- створення звітів.

Устаткування поста повинно складатися 3 виробів, що промислово випускаються, об’єднаних у єдиний функціональний вузол, який у повному обсязі виконує завдання, що ставляться перед АСМ. Для заміни поламаних блоків або виконання метрологічних робіт необхідно виконувати тільки дії, пов'язані 3 необхідністю від'єднання з'єднувачів або дротів від клем і зняття кріпильних елементів (наприклад, блоку живлення, датчика, модема і т. п.). АСМ повинна мати можливість розширення, що дозволить нарощувати кількість технічних засобів нижнього рівня.
Межі модернізації та розвитку АCM:

a) установка і включення в систему додаткових постів спостереження;

б) збільшення контрольованих параметрів на постах контролю;

в) можливість зміни контрольних і аварійних уставок, а також технологічних параметрів;

г) включення нових завдань оперативної обробки та подання інформації не повинні збільшувати завантаження обчислювальних ресурсів АРМ більш ніж до 75\% при нарощуванні програмного забезпечення до $40 \%$;

д) можливість розширення обсягу інформації, що приймається від об'єкта автоматизації, визначається наявністю резервних входів у ТЗ середнього рівня, а також портів з інтерфейсом RS-485/422;

е) можливість зміни контрольних і аварійних уставок, а також технологічних параметрів.

Аварійними уставками є величини вимірюваних параметрів середовища, за яких необхідне прийняття рішень.

АCМ повинна забезпечувати виконання в повному обсязі визначених функцій, у всіх режимах експлуатації в межах діапазонів вимірювання застосовуваних засобів вимірювання.

АCM належить до виробів безперервного, тривалого, конкретного застосування, відновлюваних, що підлягають технічному обслуговуванню i peмонту (плановому і неплановому), до яких згідно з ГОСТ 27.003 висуваються такі вимоги:

а) безвідмовність;

б) ремонтопридатність;

в) довговічність.

Гарантійний термін роботи АСМ повинен становити 12 місяців після прийняття АСМ у постійну експлуатацію.

Гарантійні зобов'язання на АСМ не поширюються на виявлення механічних пошкоджень складових частин або на порушення пломбування блоків [6-10].

Середній термін служби до першого капітального ремонту технічних засобів середнього та верхнього рівнів - не менше 3 років за умови заміни технічних засобів, які відпрацювали свій ресурс.

Надійність АСМ повинна забезпечуватися за рахунок:

а) якісного виконання технічних засобів;

б) якісного проведення монтажних робіт;

в) організаційних заходів щодо обмеження доступу до технічних засобів, програмного забезпечення;

г) технічного обслуговування (виконання профілактичних робіт) відповідно до експлуатаційної документації на АCM;

д) автоматизованих процедур тестування технічних засобів АСМ і захисту від одиничних помилок оператора;

е) сигналізації про несанкціонований доступ до технічних засобів;

ж) збереження логінів користувачів, у т. ч. і при спробі несанкціонованого доступу до системи. 
Для підвищення живучості АСМ повинна забезпечуватися можливість автономного використання технічних засобів нижнього та середнього рівня за функціями збору, попередньої обробки та зберігання інформації за останні 168 годин (7 днів) у разі пошкодження каналів зв'язків між технічними засобами середнього (АРМ) і верхнього (СЗД) рівнів [7-8].

Під відмовою АСМ слід вважати неможливість виконання таких функцій, як:

а) безперервне вимірювання значень параметрів у точках контролю;

б) автоматичне відображення вимірюваних параметрів і технологічних параметрів;

в) архівування даних системи верхнього рівня.

Разові виходи зі строю одиничних елементів (запобіжників, плавких вставок та ін.) не $\epsilon$ відмовою АCM.

Технічні засоби повинні бути розроблені таким чином, щоб вони відповідали вимогам НТД під час їх експлуатації та технічного обслуговування:

- ДНАОП 0.00-1.32-01 «Правила будови електроустановок, електроустаткування спеціальних установок»;

- НАПБ А.01.001-2004 «Правила пожежної безпеки», затвердженому наказом МНС України від 19 жовтня 2004 р. № 126;

- ПТЕ електроустановок споживачів.

Технічні засоби повинні відповідати вимогам пожежної безпеки, встановленим ГОСТ 12.2.007.0, ГОСТ 12 1.004. Можливість виникнення пожеж повинна відповідати вимогам ГОСТ 12.1.004 для кожної конструктивно завершеної одиниці.

Ергономічні рішення повинні забезпечувати зручність технічного обслуговування та ремонту відповідно до ГОСТ 12.2.049 [6-10].

Висновки. Пріоритетним напрямом чинної сьогодні системи екологічного моніторингу довкілля $є$ контроль за рівнями забруднення (хімічного, радіаційного, бактеріологічного, теплового та ін.) в компонентах навколишнього середовища. Проте головною метою екологічного моніторингу є не лише кількіс- но-якісна оцінка техногенного впливу на навколишнє середовище, а й оцінка та передбачення наслідків iii багатокомпонентної відповідної реакції для визначення загального стану екологічної безпеки.

Ведення моніторингу стану довкілля на постійній основі забезпечить отримання інформації про стан навколишнього природного середовища, що дасть можливість вчасно приймати управлінські рішення для покращення стану довкілля.

У чинній системі спостережень за станом атмосфери України збір і обробка інформації малоавтоматизовані, засновані на лабораторно-хімічних методах аналізу проб і використовуються не стільки для прийняття оперативних управлінських рішень, скільки для статистичного аналізу. Також неоптимальне функціонування системи моніторингу сьогодні зумовлене низьким рівнем уніфікації нормативно-методичної бази, технічного забезпечення та взаємодії iii суб'єктів, а також недостатнім об'ємом фінансування робіт.

Основними недоліками, що зумовлюють низьку ефективність функціонування системи моніторингу, є:

- відсутність єдиної мережі спостережень;

- застаріле технічне і методичне забезпечення спостережень;

- відсутність сучасного технічного оснащення центрів системи моніторингу в більшості регіонів;

- неузгодженість окремих елементів інформаційних технологій, які використовуються суб'єктами системи моніторингу;

- неповна відповідність нормативно-технічного та нормативно-правового забезпечення системи моніторингу сучасним вимогам.

Це, у свою чергу, практично не дає змоги відповідним органам ефективно здійснювати управління якістю повітря на різних рівнях для запобігання негативним змінам стану довкілля та дотримання вимог екологічної безпеки, що призводить до негативних наслідків для навколишнього середовища, зокрема для здоров’я населення.

\section{Список літератури:}

[1] Про охорону атмосферного повітря : Закон України від 16 жовтня 1992 р. № 2708-ХІІ. Відомості Верховної Ради України. 1992. № 50. Ст. 679.

[2] Про метрологію та метрологічну діяльність : Закон України від 03 липня 2019 р. № 1314-VII. Відомості Верховної Ради України. 2019. № 28. Ст. 116.

[3] Про затвердження Положення про державну систему моніторингу довкілля : Постанова Кабінету Міністрів України від 30 березня 1998 р. № 391.

[4] Про затвердження Порядку організації та проведення моніторингу в галузі охорони атмосферного повітря : Постанова Кабінету Міністрів України від 09 березня 1999 р. № 343.

[5] Про затвердження Правил створення та експлуатації автоматизованих систем екологічного контролю i моніторингу об'єктів підвищеної екологічної небезпеки та Регламенту створення та функціонування автоматизованих систем екологічного контролю і моніторингу об'єктів підвищеної екологічної небезпеки : Наказ Міністерства охорони навколишнього середовища України від 27 березня 2009 р. № 148.

[6] ГОСТ 34.601-89. Информационная технология. Комплекс стандартов на автоматизированные системы. Автоматизированные системы. Стадии создания. [Действителен от 1990.12.29]. Москва : Стандартинфо, 2009. $11 \mathrm{c}$. 
[7] ГОСТ 34.603-92. Виды испытаний автоматизированных систем. [Действителен от 1992.02.17]. Москва : Стандартинфо, 2009. $10 \mathrm{c}$.

[8] ГОСТ 34.601-89. Информационная технология. Комплекс стандартов на автоматизированные системы. Автоматизированные системы. Стадии создания. [Действителен от 1990.12.29]. Москва : Стандартинфо, 2009. $11 \mathrm{c}$.

[9] ДСТУ 2156-93. Безпечність промислових підприємств. Терміни та визначення. [Чиний від 1995.01.01]. Наказ від 27 грудня 1993 р. № 208.

[10] ГОСТ 34.201-89 «Виды, комплектность и обозначения документов при создании автоматизированных систем» : Постановление Государственного комитета СССР по стандартам от 24 марта 1989 г. № 664.

[11] РД 50-34.698-90 Автоматизированные системы. Требования к содержанию документов. ИПК Издательство стандартов, 2002.

[12] РД 211.0.8.107-05. Методичні рекомендації з питань створення систем моніторингу довкілля регіонального рівня : Наказ Міністерства охорони навколишнього природного середовища України від 16 грудня 2005 p. № 467.

[13] Качинський А.Б. Екологічна безпека України: системний аналіз перспектив покращення. Київ : НІСД, $2001.312 \mathrm{c}$.

[14] Качинський А.Б. Екологічна безпека України: системні принципи та методи ії формалізації. Національна безпека: украӥнський вимір. 2009. № 4. С. 71-79.

(C) Денисенко І. Ю., Іващенко Т. Г., Печений В. Л. Дата надходження статті до редакції: 25.06.2020

Дата затвердження статті до друку: 27.07.2020 